\title{
Integrating Mechanical Weeding and Planting for Reduced Labour Input in Paddy Rice under System of Rice Intensification (SRI)
}

\author{
Mercy Kangai Kathia' ${ }^{1}$, Bancy Mati ${ }^{1}$, Jackline Ndiiri ${ }^{1}$, Raphael Wanjogu ${ }^{2}$ \\ ${ }^{1}$ Jomo Kenyatta University of Agriculture and Technology, Nairobi, Kenya \\ ${ }^{2}$ Mwea Irrigation Agricultural Development Centre (MIAD), National Irrigation Board, Wanguru, Kenya \\ Email: merckathia@gmail.com, bancym@gmail.com, jacklinendiiri@gmail.com,wanjogurk@yahoo.com
}

How to cite this paper: Kathia, M.K., Mati, B., Ndiiri, J. and Wanjogu, R. (2019) Integrating Mechanical Weeding and Planting for Reduced Labour Input in Paddy Rice under System of Rice Intensification (SRI). Agricultural Sciences, 10, 121-130. https://doi.org/10.4236/as.2019.102010

Received: January 8, 2019

Accepted: February 15, 2019

Published: February 18, 2019

Copyright ( 2019 by author(s) and Scientific Research Publishing Inc. This work is licensed under the Creative Commons Attribution International License (CC BY 4.0).

http://creativecommons.org/licenses/by/4.0/

\begin{abstract}
The System of Rice Intensification (SRI) has been attributed to improvement in rice production with various attributes being accrued from application of the SRI Principles. The most notable are savings on water use and increase in yield. Alternate Wetting and Drying (AWD) has also paved way for mechanical weed control in paddy fields. One of the major constraints to adoption of SRI is the perceived increased labour input due to the careful transplanting and frequent weed control. This paper evaluates the effect of mechanization on labour input in SRI in comparison to the less mechanized farmer practice. In attempt to reduce drudgery in transplanting under SRI, the drum seeder was used to establish the rice crop by direct seeding. This was then followed by using SRI practices i.e. AWD and mechanical weeding. Direct seeding using a drum seeder was compared to transplanting in both SRI and the common farmer practice. Hand weeding was also evaluated and compared to mechanical weeding. Labour input cost was also compared to the income accrued from the yields. From the study, it was noted that direct seeding using the drum seeder reduced labour input by $97 \%$ compared to transplanting. This was possible in that in direct seeding, and there was no nursery preparation and management as in transplanting. The use of a mechanical weeder reduced labour input by $28.3 \%$ in relation to hand weeding. Labour input cost for SRI was cheaper (Kshs. 124,080 per hectare) compared to the common farmer practice (Kshs. 139,117.50 per hectare). There was more yield from the SRI practice (2.75 Ton/ha) compared to the common farmer practice (1.88 Ton/ha).
\end{abstract}

\section{Keywords}

SRI, Labour Input, Direct Seeding, Mechanical Weeding, Mwea 


\section{Introduction}

Rice production has been carried out in the world for many years. Globally, the total land under rice cultivation is estimated to be 160.6 million hectares, producing 756.7 million metric tons annually [1]. In Kenya, rice cultivation was introduced in 1907 from Asia and currently it is the third most important cereal crop in Kenya after maize and wheat. The consumption rate for rice in Kenya is increasing at $12 \%$ annually compared to $4 \%$ and $1 \%$ for wheat and maize respectively. This has been attributed to change in people's eating habits [2].

Rice planting is done using two main ways; transplanting and direct seeding. Establishment of the rice plant can be done using dry seed, pre-germinated seed or seedlings depending on locality, soil type and crop ecosystem [3]. Direct seeding has also gained popularity over time and further led to reduction in production cost. A study done in Tamil Nadu, India comparing the TNAU drum seeder with SRI and the conventional methods of transplanting indicated that the drum seeder saved labour by $90 \%$ and the same saved time for sowing by 75\% [4] (Senthilkumar and Thilagm, 2012). Transplanting is done either randomly, where there is no definite distance or space between the transplanted seedlings, or in a straight row, where the plants are spaced uniformly. Manual transplanting is widely used as it requires less seed and the seedlings are able to compete for nutrients against the weeds. Mechanical transplanting is also gaining popularity mostly in Asian Countries [3] [5].

Weed management in paddy fields may be preventative, cultural, mechanical, chemical, biological or even biotechnological. Some of cultural methods of weed management in paddy fields include use of competitive cultivars. This is where a higher crop yielding variety competes with the weeds. Moisture management is also widely used since most weeds cannot germinate under flooded conditions [6]. A mechanical weeder addresses the problem of labour shortage and decreasing income per acre while reducing environmental degradation caused by herbicides. Selection of a weeding technique is purely based on improving efficiency, economics, environmental stewardship and soil conservation [7]. Chemical weed control using herbicides has gained more popularity compared to the cultural and the mechanical methods. This is because herbicides tend to use less labour input and also they've been effective when there is shortage of labour for weeding during the critical periods. Besides being an effective way of weed management, major concerns have been raised on increased environmental pollution together with change of weed flora which has been attributed to continuous use of herbicides [6].

SRI is a combination of practices that improve the productivity of rice grown in paddies. Unlike the conventional practice of continuous flooding, SRI proposes use of single, very young seedlings planted with wider spacing, intermittent wetting and drying, use of mechanical weeders and application of organic fertilizers [8]. From previous research studies, rice grown using SRI method has indicated a $25 \%-100 \%$ increase in yield while saving $25 \%-50 \%$ water input [9]. 
In Kenya, SRI was introduced in 2009 with the aim of improving food security in the country together with proper water resource management.

Since the introduction of SRI, the rate of adoption has not been smooth despite the benefits attributed to the practices. High yields and reduced water usage have been recorded by farmers who have adopted SRI. Worldwide, SRI has been adopted by over 50 countries including the major rice producers like China, India, Vietnam and the Philippines. In Africa, SRI was introduced between 2009 and 2011 and currently, more than 18 countries have introduced to the farmers [10]. In Kenya SRI adoption has grown from 2, 50, 250 to over 2000 farmers since its introduction in 2009 to 2012 [11]. In some countries like Kenya, high production cost has been attributed to migration young energetic people who provide labour in rice farms. With SRI offering opportunities to use various agricultural technologies to ensure optimum production in paddy cultivation, there is need to explore such technologies in rice production. Various studies have been done on labour input for SRI in different parts of the world which has not brought out the Kenyan scenario. A review on weed management in paddy rice in India indicated that even after introduction of high yielding rice varieties, weed management was noted to be a key factor in obtaining high yields [12] it was also noted that the cono-weeder helped to save labour, time and reduced man days required for weeding from 30 to 10 as they got accustomed to the weeder. The aim of this study was to assess the effect of mechanical weeding and planting on growing paddy rice under System of Rice Intensification with the aim of increasing the adoption rate of SRI practices.

\section{Materials and Methods}

\subsection{Site Description}

Field experiments were conducted during August-December 2015 season the Mwea Irrigation Agricultural Development (MIAD) Centre research station in Kirinyaga County, Kenya. Meteorological data was collected during the rice season from July 2015 to March 2016 at the MIAD weather station (shown in Table 1).

Table 1. Weather data during the growing season (Source; MIAD weather station).

\begin{tabular}{cccccc}
\hline Year & Month & Rainfall $(\mathrm{mm})$ & $\mathrm{T}_{\max }\left({ }^{\circ} \mathrm{C}\right)$ & $\mathrm{T}_{\min }\left({ }^{\circ} \mathrm{C}\right)$ & Relative Humidity (\%) \\
\hline 2015 & July & 0.55 & 26.54 & 15.59 & 79.45 \\
& August & 0.27 & 27.33 & 15.71 & 73.71 \\
& September & 0.00 & 29.78 & 16.47 & 63.93 \\
& October & 6.10 & 30.53 & 17.91 & 68.65 \\
& November & 12.47 & 27.85 & 17.36 & 82.57 \\
& December & 3.73 & 28.08 & 16.26 & 80.87 \\
& January & 2.22 & 28.93 & 16.89 & 79.58 \\
& February & 1.70 & 30.78 & 15.57 & 73.66 \\
& March & 2.32 & 32.63 & 18.49 & 76.65 \\
\hline
\end{tabular}




\subsection{Experimental Design}

The experimental design used was Completely Randomized Design (CRD) with four treatments; Treatment 1 (T1) - Full use of SRI practices which involved; Transplanting eight (8) days old seedlings one plant per hill with a $25 \mathrm{~cm} \times 25$ $\mathrm{cm}$ spacing. Alternate Wetting and Drying (AWD) was used for water management where plots were left dry for 4 - 5 days before wetting again. Weed management was done using a cono-weeder.

Treatment 2 (T2) - Direct seeding coupled with SRI practices. That is, pre-germinated seeds were directly planted using the TNAU drum seeder. The seed drop spacing was $20 \mathrm{~cm} \times 8 \mathrm{~cm}$. This was followed by AWD and mechanical weed control. Treatment 3 (T3) - Direct seeding using the TNAU drum seeder coupled with Farmer practice commonly used in Mwea, Kenya and Treatment 4 (T4) -Full farmer practice which involves transplanting twenty-one 21 days old seedlings in clumps of 4 - 6 plants per hill with no definite spacing. Weed management was done through hand weeding. For every treatment there were three replications. The plot size used was $16 \mathrm{~m} \times 6 \mathrm{~m}$ and the variety of rice planted was Basmati 370 .

\subsection{Data Collection and Analysis}

\subsubsection{Land and Nursery Preparation}

The field was soaked for 5 days which was followed by ploughing. Harrowing was done 2 times with a 3-day pause to ensure proper soil-water mixture. Field levelling was done to ensure that water reaches all parts of the field. This was then followed by plot separation for different treatments. For SRI plots grid marking was done before transplanting to achieve the $25 \mathrm{~cm} \times 25 \mathrm{~cm}$ spacing. Nursery preparation was done in concurrently with land preparation. A section of the field was set aside or the SRI and the Continuous Flooding nursery beds.

\subsubsection{Data Collection Procedures}

The study aimed to establish the effect of introduction of a drum seeder for planting and the push weeder for weed management in rice farms in relation to the use of human labour during transplanting and weeding. This was achieved by comparing labour input in plots where mechanization was applicable and where human labour is widely used. During planting, the time taken for direct seeding using the drum seeder was compared to the time taken for raising and managing a nursery for the transplanted rice. This included the amount of labour used in preparing the nursery beds, bird scaring and the actual transplanting.

Transplanting labour was defined by timing the rate of transplanting one plot of SRI versus one plot of CF considering the number of people involved in the activity. This was then converted to man-hours per hectare. Labour input for transplanting was compared to the time taken for direct seeding using the drum seeder. This was achieved by getting the time taken or the drum seeder to move from one end to the other and then getting the average time taken for all the 
rounds done by the drum seeder.

For every plot, labour input for weeding per unit area was evaluated and the variation was as a result of the different cropping system and operations performed on the plot. Mechanical weeding was compared to hand weeding

Labour input was also defined by establishing time taken to completely weed a plot either by hand and machine taking into account the number of people involved in the activity.

\section{Results}

\subsection{Direct Seeding in Comparison to Transplanting}

Direct seeding using the TNAU drum seeder used the least labour input for planting compared to transplanting in both SRI and the common farmer practice as (shown in the Table 2).

\subsection{Comparison of Mechanical Weeding and Hand Weeding}

In weed management, the mechanical weeder less laborious in SRI and in the direct sown plots compared to where hand weeding was purely used. Comparison for labour input for weed management using the mechanical weeder and hand weeding is shown in Table 3.

Comparing the means for weeding there was a difference as shown in Table 4.

\subsection{Comparison of Mechanical Weeding in SRI and Direct Seeded Rice}

The mechanical weeder was in Treatment 1 (Full SRI) and in the directly seeded plots, Treatment 2 and Treatment 3 . This is where the plants were established in rows. In SRI there was less labour input compared to the directly seeded plots. Table 5 and Table 6 show the labour input and ANOVA for mechanical weeding respectively.

Table 2. Labour input for planting.

\begin{tabular}{cc}
\hline Treatment & Time for planting (MHrs/Ha) \\
\hline Full SRI & 156.12 \\
DS \& SRI & 2.25 \\
DS \& CF & 2.31 \\
Full CF & 79.68 \\
\hline
\end{tabular}

Table 3. Labour input for weeding.

\begin{tabular}{cccc}
\hline Treatment & $\mathbf{1}^{\text {st }}$ weeding MHrs/ha & $\mathbf{2}^{\text {nd }}$ weeding MHrs/ha & $\mathbf{3}^{\text {rd }}$ weeding MHrs $/$ ha \\
\hline Full SRI & 82.98 & 45.3 & 40.69 \\
DS \& SRI & 81.25 & 65.98 & 61.73 \\
DS \& CF & 80.56 & 63.71 & 53.45 \\
Full CF & 86.5 & 75.5 & 73.65 \\
\hline
\end{tabular}


Table 4. ANOVA for labour input weeding.

\begin{tabular}{ccccccc}
\hline \multicolumn{6}{c}{ SUMMARY } \\
\hline Groups & Count & Sum & Average & Variance & \\
\hline $1^{\text {st }}$ weeding M/hrs & 4 & 331.29 & 82.8225 & 7.046825 & \\
$2^{\text {nd }}$ weeding M/hrs & 4 & 250.49 & 62.6225 & 159.4515 & & \\
$3^{\text {rd }}$ weeding M/hrs & 4 & 229.52 & 57.38 & 192.5455 & & \\
ANOVA & & & & & & F crit \\
Source of Variation & SS & df & MS & F & P-value & \\
Between Groups & 1443.793 & 2 & 721.8964 & 6.031825 & 0.021787 & 4.256495 \\
Within Groups & 1077.131 & 9 & 119.6813 & & & \\
Total & 2520.924 & 11 & & & & \\
\hline
\end{tabular}

Table 5. Labour input for mechanical weeding.

\begin{tabular}{cccc}
\hline Treatment & $\mathbf{1}^{\text {st }}$ weeding MHrs & $\mathbf{2}^{\text {nd }}$ weeding MHrs & $\mathbf{3}^{\text {rd }}$ weeding MHrs \\
\hline Full SRI & 82.98 & 45.3 & 40.69 \\
DS \& SRI & 81.25 & 65.98 & 61.73 \\
DS \& CF & 80.56 & 63.71 & 53.45 \\
\hline
\end{tabular}

Table 6. ANOVA for mechanical weeding only.

\begin{tabular}{|c|c|c|c|c|c|c|}
\hline \multicolumn{7}{|c|}{ SUMMARY } \\
\hline Groups & Count & Sum & Average & Variance & & \\
\hline $1^{\text {st }}$ weeding MHrs & 3 & 244.79 & 81.59667 & 1.554233 & & \\
\hline $2^{\text {nd }}$ weeding MHrs & 3 & 174.99 & 58.33 & 128.6239 & & \\
\hline 3rd weeding MHrs & 3 & 155.87 & 51.95667 & 112.3429 & & \\
\hline \multicolumn{7}{|l|}{ ANOVA } \\
\hline Source of Variation & SS & df & MS & $\mathrm{F}$ & P-value & F crit \\
\hline Between Groups & 1460.487 & 2 & 730.2434 & 9.033154 & 0.015496 & 5.143253 \\
\hline Within Groups & 485.0421 & 6 & 80.84036 & & & \\
\hline Total & 1945.529 & 8 & & & & \\
\hline
\end{tabular}

\subsection{Labour Input Cost in Comparison to Income from Yields}

Labour input for various activities in all the treatments was quantified and costed to establish the cost of labour for activities involved in growing paddy rice (shown in Table 7).

In order to see whether mechanization was beneficial to SRI labour input cost was compared to the yields for all the treatments (shown in Figure 1). The yields from all treatments (shown in Table 8) were also costed at the market price of paddy rice in Mwea, Kenya. 


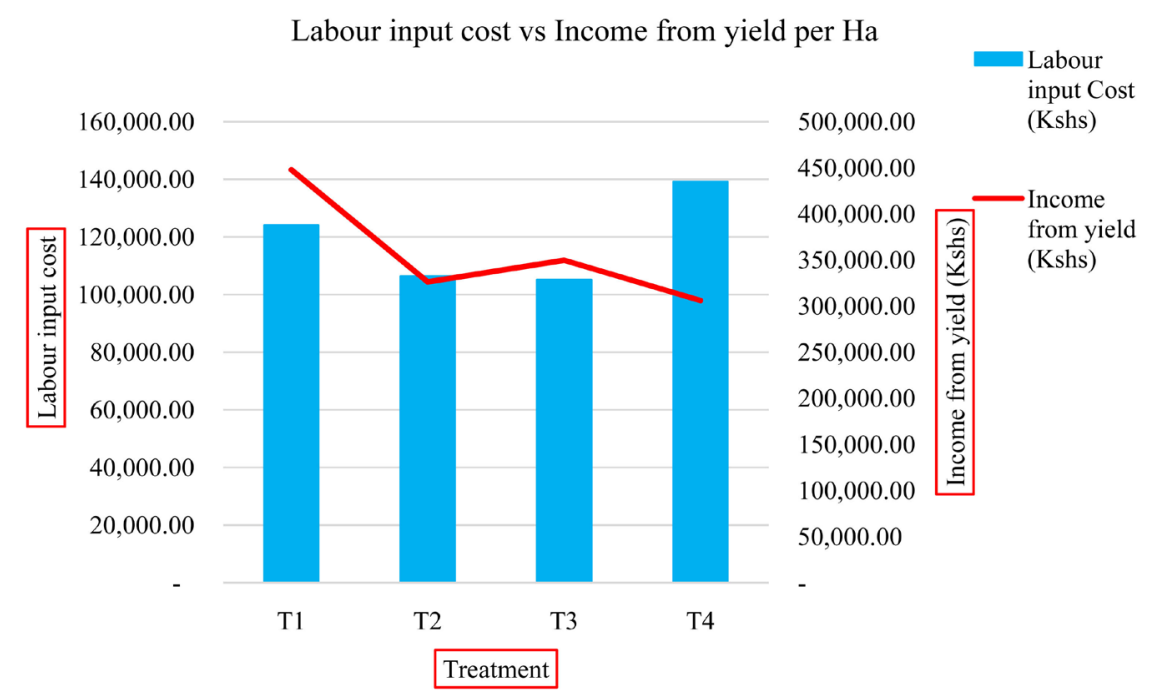

Figure 1. Comparison of labour input cost with income from yields.

Table 7. Labour input cost.

\begin{tabular}{|c|c|c|c|c|c|c|c|c|c|c|c|}
\hline \multicolumn{12}{|c|}{ TREATMENT } \\
\hline \multirow[b]{2}{*}{ S/No } & \multirow[b]{2}{*}{ Particulars } & \multirow[b]{2}{*}{ Unit } & \multirow{2}{*}{$\begin{array}{l}\text { Unit Cost } \\
\text { (at Mwea) }\end{array}$} & \multicolumn{2}{|r|}{$\mathrm{T} 1$} & \multicolumn{2}{|r|}{$\mathrm{T} 2$} & \multicolumn{2}{|r|}{ T3 } & \multicolumn{2}{|r|}{$\mathrm{T} 4$} \\
\hline & & & & $\begin{array}{l}\text { Unit } \\
\text { used }\end{array}$ & $\begin{array}{l}\text { Total Cost } \\
\text { (Kshs) }\end{array}$ & $\begin{array}{l}\text { Unit } \\
\text { used }\end{array}$ & $\begin{array}{l}\text { Total Cost } \\
\text { (Kshs) }\end{array}$ & $\begin{array}{l}\text { Unit } \\
\text { used }\end{array}$ & $\begin{array}{l}\text { Total Cost } \\
\text { (Kshs) }\end{array}$ & $\begin{array}{l}\text { Unit } \\
\text { used }\end{array}$ & $\begin{array}{l}\text { Total Cost } \\
\text { (Kshs) }\end{array}$ \\
\hline 1 & $\begin{array}{l}\text { Land preparation } \\
\text { (ploughing, puddling, } \\
\text { harrowing, levelling) }\end{array}$ & Hectare & 6000 & 2.5 & $15,000.00$ & 2.5 & $15,000.00$ & 2.5 & $15,000.00$ & 2.5 & $15,000.0$ \\
\hline 2 & Nursery Preparation & $\mathrm{M} / \mathrm{D}$ & 350 & 25 & 8750.00 & 0 & - & 0 & - & 57.5 & $20,125.0$ \\
\hline 3 & seed rate & Kgs & 95 & 5 & 475.00 & 37.5 & 3562.50 & 37.5 & 3562.50 & 50 & 4750.0 \\
\hline 4 & $\begin{array}{l}\text { Seed preparation } \\
\text { (soaking \& sowing) }\end{array}$ & $\mathrm{M} / \mathrm{D}$ & 350 & 5 & 1750.00 & 5 & 1750.00 & 5 & 1750.00 & 5 & 1750.0 \\
\hline 5 & Planting & $\mathrm{M} / \mathrm{D}$ & 350 & 47.5 & $16,625.00$ & 0.7 & 245.00 & 0.725 & 253.75 & 24.9 & 8715.0 \\
\hline 6 & Weeding & $\mathrm{M} / \mathrm{D}$ & 350 & 52.8 & $18,480.00$ & 65.3 & $22,855.00$ & 61.8 & $21,630.00$ & 73.65 & $25,777.5$ \\
\hline 7 & Bird Scaring & $\mathrm{M} / \mathrm{D}$ & 400 & 75 & $30,000.00$ & 75 & $30,000.00$ & 75 & $30,000.00$ & 75 & $30,000.0$ \\
\hline 8 & Harvesting & $\mathrm{M} / \mathrm{D}$ & 400 & 37.5 & $15,000.00$ & 37.5 & $15,000.00$ & 37.5 & $15,000.00$ & 37.5 & $15,000.0$ \\
\hline 9 & $\begin{array}{c}\text { Post-harvest } \\
\text { Handling } \\
\text { (winnowing \& drying) }\end{array}$ & $\mathrm{M} / \mathrm{D}$ & 400 & 45 & $18,000.00$ & 45 & $18,000.00$ & 45 & $18,000.00$ & 45 & $18,000.0$ \\
\hline & TOTAL (KSHS) & & & & $124,080.00$ & & $106,412.50$ & & $105,196.25$ & & $139,117.50$ \\
\hline
\end{tabular}

Table 8. Income from yields.

\begin{tabular}{cccc}
\hline Treatment & Yield (Kg)/HA & Unit cost (Kshs) & Total Cost (Kshs) \\
\hline T1 & 6890 & 65 & 447,850 \\
T2 & 5020 & 65 & 326,300 \\
T3 & 5380 & 65 & 349,700 \\
T4 & 4710 & 65 & 306,150 \\
\hline
\end{tabular}




\section{Discussion}

The use of the drum seeder for direct seeding resulted in reduction of labour input by $97 \%$ compared to transplanting for both SRI and CF. this because, in direct seeding there was no nursery established. This resonates with previous studies done in Tamil Nadu comparing the drum seeder with SRI and the conventional method of planting. The pre-germinated seeds were directly sown by use of the drum seeder and this required between 2.25 and 2.31 MHrs/ha compared to transplanting which required 156.12 and $79.68 \mathrm{MHrs} / \mathrm{ha}$ for SRI and CF respectively. Considering one of the biggest hindrances to adoption of SRI is drudgery during transplanting, direct seeding reduces the labour input and also the time taken for planting paddy rice. This in turn reduced the production cost for directly sown rice.

In plots where the rice crops were established in rows, T1, T2 and T3, weed management was done using a mechanical push weeder. The push weeder was more preferable as it was less labour intensive and less time consuming. It was also preferable as it reduced stress caused by bending all the time to remove weeds. In T1, there was ease in using the push weeder due to the $25 \mathrm{~cm} \times 25 \mathrm{~cm}$ spacing which allowed the weeder to move in all directions. This resulted in labour savings compared to the other treatments. The average labour input for weeding in T1 was 56.3 MHrs/ha that is, $82.98 \mathrm{MHrs} / \mathrm{ha}$, 45.3 MHrs/ha and 40.69 $\mathrm{MHrs} / \mathrm{ha}$ for the first, second and third weeding respectively. During the first weeding, more labour was used in T1, T2 and T3 compared to the preceding weeding activities. This is because the operator was using the weeder for the first time. With time, as seen in the second and third weeding, the input requirement goes down as the get used to the weeder. In T2 and T3, the weeder could only move in one direction since the $20 \mathrm{~cm} \times 8 \mathrm{~cm}$ spacing did not allow for weeder movement in all directions. Again, the weeding was done carefully to avoid damaging the plants since during planting, the drum seeder did not establish definite rows. This resulted to increase in labour input by $23.5 \%$ compared to $\mathrm{T} 1$.

In T4, hand weeding was used for weed management and there was an increase in labour input compared to the other treatments. Hand weeding used $39.5 \%, 13.1 \%$ and $19.2 \%$ more labour input in comparison to $\mathrm{T} 1, \mathrm{~T} 2$ and $\mathrm{T} 3 \mathrm{re}-$ spectively.

\section{Conclusion}

Establishment of the crops in rows has given rice farming an opportunity to mechanize various operations in rice farming. From the study, the use of a mechanical weeder reduced labour input by $28.3 \%$ in relation hand weeding. Direct seeding using a drum seeder also allowed for mechanical weeding though in one direction which reduced labour input by $11 \%$ and $16 \%$ compared to hand weeding. The cost of labour input per acre was lowest in the direct seeded plots with T2 at Kshs. 42,565 and T3 at Kshs. 42,077.80. Labour input cost in the common farmer practice was Kshs. 55,647 compared to Kshs. 49,632 in the SRI plots. 
Income from the yield was highest in the SRI plot at Kshs. 179,140 compared to Kshs. 139,880 and 130,520 in the direct seeded plots. Yield income was lowest in the common farmer practice (Kshs. 122,460). The mechanical weeder compliments SRI by reducing labour input while increasing yields as noted by other researchers.

\section{Acknowledgements}

This research was funded by the African Institute for Capacity Development (AICAD) and much support from Jomo Kenyatta University of Agriculture and Technology (JKUAT) and the Mwea Irrigation Agricultural Development Centre. Most Sincere appreciation to my supervisors for their guidance and input throughout my research. I acknowledge immense help from various scholars whose articles are cited.

\section{Conflicts of Interest}

The authors declare no conflicts of interest regarding the publication of this paper.

\section{References}

[1] Food and Agriculture Organization (2017) Rice Market Monitor December 2017. VOLUME XX ISSUE No. 4. http://www.fao.org/economic/RMM

[2] Ministry of Agriculture (MOA) (2009) National Rice Development Strategy (2008-2018). Republic of Kenya.

[3] International Rice Research Institute (IRRI) (2014) Rice Production Manual

[4] Senthilkumar, T. and Thilagm, V.K. (2012) Comparative Study on Improved TNAU Drum Seeder with SRI and Conventional Methods of Transplanting. Madras Agricultural Journal, 99, 629-630.

[5] Thakur, A.K., Roy Chowdhury, S., Kundu, D.K. and Singh, R. (2004) Evaluation of Crop Establishment Methods in Irrigated Rice. Archives of Agronomy and Soil Science, 50, 631-640. https://doi.org/10.1080/08927010400011278

[6] Mishra, J.S., Singh, V.P., Rao, A.N. and Kumar, R. (2016) Chapter: Weed Management in Major Field Crops. In: Advances in Weed Management, Indian Society of Agronomy, 1-21.

[7] Pandit, S.V., Kedar, P., Swati, B.G., Ranjeet, M. and Rajigare, P. (2016) Mechanical Portable Power Weeder Machine. International Journal of Research in Advanced Engineering and Technology, 2, 31-34.

[8] Uphoff, N. (2006) The System of Rice Intensification (SRI) as a Methodology for Reducing Water Requirements in Irrigated Rice Production. International Dialogue on Rice and Water. Exploring Options for Food Security and Sustainable Environments, held at IRRI, Los Baños, Philippines, 7-8 March 2006.

[9] Satyanarayana, A., Thiyagarajan, T.M. and Uphoff, N. (2006) Opportunities for Water Saving with Higher Yield from the System of Rice Intensification. Irrigation Science, 25, 99-115. https://doi.org/10.1007/s00271-006-0038-8

[10] Katambara, Z., Kahimba, F.C., Mahoo, H.F., Mbungu, W.B., Reuben, P., Mango, M. and Nyambamba, A. (2013) Adopting the System of Rice Intensification (SRI) in Tanzania. Agricultural Sciences, 4, 369-375. 
https://doi.org/10.4236/as.2013.48053

[11] Ndiiri, J.A., Mati, B.M., Home, P.G., Odongo, B. and Uphoff, N. (2013) Benefit-Cost Analysis of Paddy Rice under the System of Rice Intensification in Mwea, Kenya. Scientific Conference Proceedings, February 2013.

[12] Parameswari, Y.S. and Srinivas, A. (2017) Weed Management in Rice-A Review. International Journal of Applied and Pure Science and Agriculture, 3, Issue 1. 